\title{
Turkey Urticaria Diagnosis and Treatment Guide based; Distribution of Chronic Urticaria Patients Treated in Our Clinic According to Step Therapy
}

\section{Türkiye Ürtiker Tanı ve Tedavi Kılavuzu Baz Alınarak Kliniğimizde Tedavi Edilen Kronik Ürtikerli Hastaların Basamak Tedavisine Göre Dağılımı}

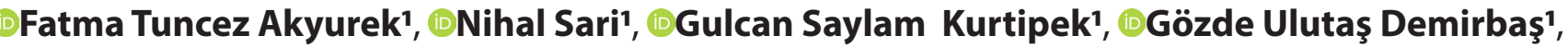 \\ (D)Emre Zekey', DMehmet Akyurek', @Neriman Akdam²
}

'Selcuk University, Faculty of Medicine, Department of Dermatology, Konya, Turkey

${ }^{2}$ Selcuk University, Faculty of Medicine, Department of Biostatistics, Konya, Turkey

\begin{abstract}
Aim: Chronic urticaria is a condition that requires long-term treatment. In recent years, many countries have created their own guides to evaluate urticaria diagnosis and treatment approaches in an algorithm. In this study, we aimed to evaluate the distribution of patients with chronic urticaria treated in our clinic according to the treatment algorithm the "Turkey Urticaria Diagnosis and Treatment Guide"

Material and Method: The files of the patients who applied to the dermatology clinic of our hospital and were followed up and treated with a diagnosis of chronic urticaria were investigated.

Results: A total of 102 patients with chronic urticaria were included in the study. According to this guide, $17.6 \%$ of patients responded with standard dose antihistamine therapy, while the antihistamine dose given in $15.7 \%$ of patients was increased. The antihistamine treatment of $5.7 \%$ of patients was replaced by a different group of antihistamines at the same dose as the previous one. $52 \%$ of patients responded to omalizumab $300 \mathrm{mg} / \mathrm{subcutaneous}$ treatment every 28 days. However, $7.8 \%$ of the patients received omalizumab treatment every 14 days or cyclosporine treatment was required to be added to omalizumab treatment. Response to other treatments other than standard treatments was received in $1 \%$ of patients.

Conclusion: We believe that our study will facilitate predicting the treatment responses of patients in clinical practice by shedding light on the distribution of chronic urticaria patients according to the treatment algorithm.
\end{abstract}

Keywords: Cyclosporine, omelizumab, treatment, urticaria
Öz

Amaç: Kronik ürtiker, uzun süreli tedavi gerektiren bir durumdur. Son yıllarda birçok ülke ürtiker tanı ve tedavi yaklaşımlarını bir algoritmada değerlendirmek için kendi kılavuzlarını oluşturmuştur. Bu çalışmada, kliniğimizde tedavi gören kronik ürtikerli hastaların "Türkiye Ürtiker Tanı ve Tedavi Rehberi" tedavi algoritmasına göre dağılımını değerlendirmeyi amaçladık.

Gereç ve Yöntem: Hastanemiz dermatoloji kliniğine başvuran ve kronik ürtiker tanısıyla takip ve tedavi edilen hastaların dosyaları incelendi.

Bulgular: Çalışmaya toplam 102 kronik ürtikerli hasta dahil edildi. Bu kılavuza göre hastaların\% 17,6'sı standart doz antihistaminik tedavisine yanıt verirken, hastaların\% 15,7'sinde verilen antihistaminik dozu artırıldı. Hastaların\% 5.7'sinin antihistaminik tedavisi, önceki ile aynı dozda farklı bir antihistaminik grubu ile değiştirildi. Hastaların\% 52'si 28 günde bir 300 mg/subkutan omalizumab tedavisine yanıt verdi. Ancak hastaların\% 7,8'i 14 günde bir omalizumab tedavisi almış veya omalizumab tedavisine siklosporin tedavisi eklenmesi gerekmiştir. Standart tedaviler dışındaki diğer tedavilere yanıt hastaların\% 1 'inde alınmıştır.

Sonuç: Çalışmamızın, kronik ürtiker hastalarının tedavi algoritmasına göre dağııımına ışık tutarak klinik pratikte hastaların tedavi yanıtlarını tahmin etmeyi kolaylaştıracağına inanıyoruz.

Anahtar Kelimeler: Siklosporin, omalizumab, tedavi, ürtiker

Corresponding (illetişim): Fatma Tuncez Akyurek, Selçuk Üniversitesi Tıp Fakültesi Hastanesi, Deri ve Zührevi Hastalıklar Anabilim Dalı, Alaeddin Keykubad Kampüsü, 42075, Selçuklu, Konya, Türkiye

E-mail (E-posta): dermafatma@yahoo.com.tr

Received (Geliş Tarihi): 21.12.2020 Accepted (Kabul Tarihi): 30.12 .2020 


\section{INTRODUCTION}

Urticaria is a skin disease that is frequently seen in all communities, characterized by itchy and edematous plaques that appear suddenly and disappear spontaneously within 24 hours. The clinical picture lasting less than 6 weeks is defined as acute urticaria, and urticaria that occurs continuously or at intervals for at least 6 weeks is also defined as chronic urticaria. ${ }^{[1,2]}$ The prevalence of chronic urticaria in the general population is between $0.5 \%$ and $5 \%$. The most important cell in the pathogenesis of chronic urticaria is mast cells in the skin, and its dominant mediator is histamine. ${ }^{[2]}$ In its treatment, agents that target these factors, which play a major role in pathogenesis, are used. "Turkey is the Urticaria Diagnosis and Treatment Guide" by management of chronic urticaria; it is based on avoiding trigger factors and symptomatic treatment. The gold standard of symptomatic first-line therapy; the second generation is the standard dose use of $\mathrm{H} 1$ antihistamines. If symptoms cannot be controlled within 1-2 weeks, in the second step, the current antihistamine dose is increased up to four times. ${ }^{[3]}$ If it is still unresponsive, switch to another antihistamine at the last used dose or add leukotriene receptor antagonists. Biological agents are involved in tertiary therapy, now the only treatment approved for antihistamine-resistant chronic urticaria is omalizumab. If the response to 24week omalizumab treatment cannot be obtained, the dose of omalizumab is increased or cyclosporine may be given instead. Or cyclosporine can be added to the current omelizumab treatment. Despite all these, if the symptoms cannot be controlled, other treatments (methotrexate, phototherapy, dapson IVIG, etc.) can be tried. ${ }^{[3-5]}$

Our aim in this study, "Turkey Urticaria Diagnosis and Treatment Guide" is based on; the evaluation of the distribution of patients with chronic urticaria treated in our clinic according to the step treatment in the guide.

\section{MATERIAL AND METHOD}

The study was approved by the Local Ethics Committee of Selcuk University Faculty of Medicine (approval number: 2020/192). The files of 102 patients who were admitted to the Department of Dermatology of Selçuk University, followed up and treated with the diagnosis of chronic urticaria without angioedema were scanned from the hospital registry system and evaluated retrospectively. Patients' age, gender, disease duration, etiological factors, comorbidities, urticaria severity, and response treatment steps were recorded. Data Frequency $(n)$ and percentage (\%) for categorical data, minimum, maximum, mean \pm standard deviation and median descriptive statistics were made for continuous data. The Chi-Square test was used to test whether there is a relationship between the severity of the disease and gender. The chi-square test was evaluated at 5\% significance level (95\% confidence level).

\section{RESULTS}

A total of 102 patients with chronic urticaria, 33 male and 69 female, without angioedema, were included in the study. $67.6 \%$ of all patients were female and mean age was $43 \pm 16$. $32.4 \%$ of the patients were male and mean age was $42 \pm 18$. When the etiological factors of patients with chronic urticaria are evaluated; while $42.2 \%$ had stress factor alone, $36.3 \%$ were idiopathic and $21.5 \%$ were multifactorial (combination of drug use, emotional stress and other factors). Disease severities were evaluated in routine clinical practice, $24.5 \%$ of patients had mild, 50\% moderate and $25.5 \%$ severe disease. The average disease duration was 64 months. The distribution of patients was evaluated according to the treatment steps in "Turkey Urticaria Diagnosis and Treatment Guide". According to this guide, $17.6 \%$ of patients responded with standard dose antihistamine therapy, while the antihistamine dose given in $15.7 \%$ of patients was increased. Antihistamine treatment of $5.7 \%$ of patients was switched by a different group of antihistamines at the same dose as before. 52\% of patients responded to omalizumab $300 \mathrm{mg} / \mathrm{subcutaneous} \mathrm{treatment}$ every 28 days. However, in $7.8 \%$ of patients, the use of omalizumab therapy every 14 days or additional cyclosporin treatment was required. $1 \%$ of all patients did not benefit from standard treatments, these patients responded to other treatments (IVIG, Dapson, Methotrexate). Short-course corticosteroid therapy was used in cases when the disease exacerbated.

\section{DISCUSSION}

In our study, it was found that more than half of the chronic urticaria patients who were followed and treated in our clinic according to "Turkey Urticaria Diagnosis and Treatment Guide" benefit from omalizumab treatment. We attribute this rate, which we found higher than previous literature, to being a tertiary health institution and to follow up resistant patient groups in our clinic. ${ }^{[6,7]}$ The gender distribution of our patients was found 2 times more often in women than in men, similar to the literatüre. ${ }^{[6,8]}$ The mean age and gender of our patients were similar to other literature data. ${ }^{[9]}$ In our study, the average disease duration was observed longer than the literature. [10] According to the reference guideline, while the etiology of the majority of patients was idiopathic, chronic urticaria triggered by emotional stress was found more frequently in our study. ${ }^{[3]}$ When the male and female genders were evaluated separately, there was no significant difference in terms of disease severity. $17.6 \%$ of patients responded well to standard dose antihistamine therapy. This rate is similar to the literature data. $39.2 \%$ of the patients responded well to high dose antihistamine/high dose different group antihistamine use. This rate is less than the literature. $37.5 \%$ of patients with antihistamine dose increase were using montelukast. 39.6\% of patients receiving omalizumab gave adequate clinical response to omalizumab treatment alone without the need for antihistamine or montelukast treatment, this rate was similar to the literature. ${ }^{[6]}$ 
We believe that our study will facilitate predicting the treatment responses of patients in clinical practice by shedding light on the distribution of chronic urticaria patients according to the treatment steps. The limitations of our study are as follows; urticaria activity score was not used in the evaluation of the treatment response, a subjective evaluation was made, the response to the treatment was based on clinical observational data and foods that played an important role in the etiological factors were not evaluated.

\begin{tabular}{lc}
\hline \multicolumn{2}{l}{ Table 1. Demographic and clinical characteristics of patients } \\
\begin{tabular}{lc} 
Gender & $\mathbf{n ~ ( \% )}$ \\
\hline Male & $33(32.4)$ \\
Female & $69(67.6)$ \\
Age mean \pm sd; median(min-max) & $42 \pm 16 ; 42(1-84)$ \\
Disease duration (month) mean \pm sd; median (min-max) & $64 \pm 84 ; 24(2-360)$ \\
Etiological factors & $\mathbf{n ~ ( \% )}$ \\
Emotional stress & $43(42.2)$ \\
Idiopathic & $37(36.3)$ \\
Infection & $5(4.9)$ \\
Drug & $2(2.0)$ \\
Other* & $8(7.9)$ \\
Multifactorial & $7(6.7)$ \\
Disease severties & $\mathbf{n ~ ( \% )}$ \\
$\quad$ Mild & $25(24.5)$ \\
Moderate & $51(50.0)$ \\
$\quad$ Severe & $26(25.5)$ \\
\hline *Thyroid disease, asthma, allergic rhinitis, bee sting, tooth decay history, surgery history, collagen \\
tissue disease \\
nnumber, Sd:standard deviation, min-max: minimum-maximum
\end{tabular} \\
\hline
\end{tabular}

\section{ETHICAL DECLARATIONS}

Ethics Committee Approval: The study was approved by the Local Ethics Committee of Selcuk University Faculty of Medicine (approval number: 2020/192).

Informed Consent: Because the study was designed retrospectively, no written informed consent form was obtained from patients.

Referee Evaluation Process: Externally peer-reviewed.

Conflict of Interest Statement: The authors have no conflicts of interest to declare.

Financial Disclosure: The authors declared that this study received no financial support..

Author Contributions: All of the authors declare that they have all participated in the design, execution, and analysis of the paper, and that they have approved the final version.

\section{REFERENCES}

1. Maurer M, Weller K, Bindslev-Jensen C, Giménez-Arnau A, Bousquet PJ, Bousquet J, et al. Unmet clinical needs in chronic spontaneous urticaria. A GA²LEN task force report. Allergy. 2011;66(3):317-30.

2. Bernstein JA, Lang DM, Khan DA, Craig T, Dreyfus D, Hsieh F, et al. The diagnosis and management of acute and chronic urticaria: 2014 update. J Allergy Clin Immunol. 2014;133(5):1270-7.
3. Goncu EK, Aktan S, Atakan N, Baskan EB, Erdem T, Koca R, et al. The Turkish Guideline for the Diagnosis and Management of Urticaria-2016. TurkdermTurkish Archives of Dermatology and Venerology. 2016;50(3):82-98.

4. Kocaturk E, Zuberbier T. New biologics in the treatment of urticaria. Curr Opin Allergy Clin Immunol. 2018;18(5):425-31.

5. Zuberbier T, Aberer W, Asero R, Abdul Latiff AH, Baker D, Ballmer-Weber $B$, et al. The EAACI/GA(2)LEN/EDF/WAO guideline for the definition, classification, diagnosis and management of urticaria. Allergy. 2018;73(7):1393-414.

6. Marin-Cabanas I, Berbegal-de Gracia L, de Leon-Marrero F, Hispan P, Silvestre JF. Management of Chronic Spontaneous Urticaria in Routine Clinical Practice Following the EAACI/GA(2)LEN/EDF/WAO Guidelines. Actas Dermosifiliogr. 2017;108(4):346-53.

7. Kibsgaard L, Lefevre AC, Deleuran M, Vestergaard C. A case series study of eighty-five chronic spontaneous urticaria patients referred to a tertiary care center. Ann Dermatol. 2014;26(1):73-8.

8. Maurer M, Sofen H, Ortiz B, Kianifard F, Gabriel S, Bernstein JA. Positive impact of omalizumab on angioedema and quality of life in patients with refractory chronic idiopathic/spontaneous urticaria: analyses according to the presence or absence of angioedema. J Eur Acad Dermatol Venereol. 2017;31(6):1056-63.

9. Wang L, Ke X, Kavati A, Wertz D, Huang Q, Willey VJ, et al. Real-world treatment patterns and outcomes of omalizumab use in patients with chronic idiopathic urticaria. Curr Med Res Opin. 2018;34(1):35-9.

10. Erdem Y, Altunay I, Özkur E, Sivaz O. The Etiological Evaluation of Patients with Chronic Urticaria. The Medical Bulletin of Sisli Etfal Hospital. 2018;0(0). 